\title{
MUSLIM DIASPORA DALAM ISU IDENTITAS, GENDER, DAN TERORISME
}

Aji Damanur

\begin{abstract}
Theword Diaspara has been undastood as thedissemination of cetain group of peeple-ndably the Jevish and Chinese to other country or land while keeping in tourh alturallywiththecountry of theircrign Thispaper disassesthisndion of Diasparain the caseof Mudimsbyrdatingit totheproblens ofidentity, gender andterorism Thepaper asks whther Musimmigation to other countries is a form of shameor honor both for Musins thensdves and for the cuntry of their destination. Thethreekeyissues that weraisewill be used as both indicators and framevork within which the notion of Mudim sdf-esteem is investigated Theundadiningvienthat higlights thewhdeargument of the paper is that a geat majoity of Musims in Diaspora has not been able to associate ailturally with the cantry of destination, hencecreating a tension with thelocal alture

Keywords: Diaspara, nigation, idantities, genda, teronism Musim
\end{abstract}

\section{Pendahuluan}

D ewasa ini hubungan Islam-Barat memasuki era baru karena beberapa sebab. Petama, populasi muslim di Barat berkembang baik karena faktor diasporik maupun karena faktor konversi orang Barat ke Islam yang berpengaruh terhadap aspek politik, sosial dan ekonomi. Keedua, kehadiran Islam yang semakin mengglobal juga diikuti kecenderungan peningkatan politik beridentitas keislaman di mana-mana, termasuk di Barat. Ketiga, ada kerentanan hubungan antara keduanya yang diwarisi oleh saling ketidakpercayaan (mistrust) yang berakar mendalam berangkat dari faktor sejarah terutama memori traumatis Perang Salib. Bagi Muslim, Barat identik dengan dominasi-perkasa, eksploitatif, berstandar ganda, terutama dalam masalah Palestina, Afganistan, Irak dan kebijakan luar negeri lainnya. Sementara bagi Barat, umat Islam identik dengan kekerasan (terorisme), melanggar hak asasi manusia anti gender dan anti demokrasi. D engan demikian, muslim dasporik dihadapkan pada isu-isu sensitif yang harus mereka selesaikan supaya dapat diterima oleh lingkungannya. Tindakan terorisme yang dilakukan oleh orang Islam misalnya, meskipun di lokasi yang berbeda, telah mengusik ketenangan muslim diasporik di seluruh dunia. Di sisi lain, perkembangan teknologi komunikasi telah menjadi berkah tersendiri bagi muslim diasporik untuk menjalin hubungan silat al-rahimdan intelektual, minimal memperkenalkan, atau menjadi sarana memahamkan Barat atas pandangan yang keliru terhadap Islam, bahkan juga bisa menjadi jaringan pengembangan pemikiran, budaya dan peradaban yang lebih baik.

Beberapa muslim diaspork telah memberi kontribusi besar terhadap kemajuan dan pengembangan pemikiran Islam kontemporer. Misalnya Nasr Hamid A bu Zayd yang terusir dari Mesir dan tinggal di Belanda mengkampanyekan teori "analisis teks." Muhammad Arkoun, intelektual asal Aljazair yang kemudian hijrah ke Prancis, mengenalkan "pendekatan historis." Khalid Abou el Fadl, asal Kuwait yang kini tinggal di Amerika, mengenalkan hermeneutika negosiatif hukum Islam dan menjadi motor kampanye pemahaman Islam

*Sekolah T inggi Agama Islam Negeri (STAIN) Ponorogo. 
yang benar bagi masyarakat Barat, khususnya Amerika. Para pemikir diasporik tersebut bukan hanya survivedi perantauan tetapi juga mampu membangun komunikasi akademik dan sosial dengan budaya lokal di mana mereka tinggal.

Selain beberapa tokoh yang mengukir prestasi mendunia, kehidupan muslim daspora lainnya mengalami beberapa problem terkait dengan identitas, budaya, politik, implementasi ajaran agama, terutama setelah peristiwa 11 September. Isu HAM dan gender, kekerasan dan terorisme menjadi perhatian dunia, diiringi dengan ide-ide pluralisme, demokrasi dan muslim moderat. Perluasan jaringan informasi juga memberikan pengaruh signifikan pada kehidupan muslim diaspara Kekerasan/ terorisme yang dilakukan oleh beberapa muslim juga berpengaruh pada kehidupan muslim diaspora pada belahan dunia lainnya.

Ada banyak pertanyaan yang diajukan dunia Barat terhadap muslim di diaspara, sebagaimana dikemukakan Pipes, ${ }^{1}$ misalnya: apa Islam mengajarkan kekerasan, apa pendapat Islam tentang demokrasi, HAM, gender, modernitas, dan terorisme? Bahkan sering ditanyakan dengan penuh kecurigaan adalah tujuan berada di Barat: apakah anda dapat menerima bahwa negara-negara Barat adalah mayoritas Kristen dan sekuler sebagaimana adanya atau apakah anda berusaha untuk mengubahnya menjadi negara-negara mayoritas muslim yang diatur dengan hukum Islam?

Bagi muslim daspora pertanyaan-pertanyaan di atas bukan saja harus dijawab, tetapi juga membutuhkan ketegasan identitas, baik bangsa maupun agama. Mereka adalah bagian dari masyarakat setempat namun juga bagian dari dunia masyarakat Islam. Sebagai warga dari sebuah negara, mereka memiliki identitas nasionalisme dari negara yang ditinggali meskipun mereka adalah minoritas dari hamparan mayoritas non muslim, sementara sisi yang lain mereka setia dengan khazanah ketauhidan yang bersifat global. Inilah problem identitas yang dihadapi muslim daspara yang berimplikasi pada seluruh aspek bangunan masyarakat diaspora.

Oleh karena itu, menarik untuk mengetahui pola hidup muslim diasparik dengan berbagai aktifitas dan implikasi bagi hubungan Timur dan Barat. Tulisan ini dimaksudkan untuk mengetahui lebih mendalam tentang muslim daspara, khususnya dari segi kontribusi intelektual dan budaya dalam rangka membangun kesepahaman dan peradaban yang harmonis dengan dunia luar sembari berkontribusi pada kampung halaman secara signifikan. Isu-isu sentral tentang muslim dasporayang banyak dibicarakan di antaranya tentang identitas, gender, terorisme, dan isu-isu kemanusiaan lainnya yang menuntut sikap, perilaku dan intermediasi yang elegan sehingga kehidupan muslim daspora tidak saja sejahtera tetapi juga mampu menjadi corong komunikasi antara Timur dan Barat.

\section{Sejarah dan Konsep Diaspora}

Istilah dasparadalam bahasa Yunani kuno äéáóðiiñü berarti penyebaran atau penaburan benih. Istilah ini kemudian digunakan untuk merujuk kepada bangsa atau penduduk etnis

${ }^{1}$ D aniel Pipes adalah D irektur Forum Timur Tengah dan penulis Islam Militan telah masuk Amerika. Ia memperoleh $\mathrm{PhD}$-nya dalam kajian Sejarah Islam Awal (klasik) dari Universitas Harvard dan mengajar di almamaternya ini dan Universitas Chichago. Meskipun ia banyak dituduh sebagai akademisi yang bekerja untuk pemerintah, tetapi pertanyaan-pertanyaan di atas merupakan pertanyaan umum masyarakat Barat terhadap Islam. Lihat D aniel Pipes, "Mengidentifikasi Muslim Moderat," dalam Suaidi Asyari, Siapakah MusimModarat (Jakarta: G aung Persada Press, 2008), 2-4. 
manapun yang terpaksa atau terdorong untuk meninggalkan tanah air etnis tradisional mereka, penyebaran mereka di berbagai bagian lain dunia, dan perkembangan yang dihasilkan karena penyebaran dan budaya mereka. ${ }^{2}$

Mulanya, istilah diaspora digunakan oleh orang-orang Yunani untuk merujuk kepada warga suatu kota kerajaan yang bermigrasi ke wilayah jajahan dengan maksud kolonisasi untuk mengasimilasikan wilayah itu ke dalam kerajaan. Asal usul kata itu diduga dari versi Septuaginta dari Kitab Ulangan 28:25, "sehingga engkau menjadi diaspora (bahasa Yunani untuk penyebaran) bagi segala kerajaan di bumi." Istilah ini telah digunakan dalam pengertian modernnya sejak akhir abad ke-20. Makna aslinya terlepas dari maknanya yang sekarang ketika Perjanjian Lama diterjemahkan ke dalam bahasa Yunani, dan kata diaspara digunakan untuk merujuk secara khusus kepada penduduk Yahudi yang dibuang dari Yudea pada 586 M oleh Babel, dan Yerusalem pada 135 M oleh kekaisaran Romawi. Istilah ini digunakan berganti-ganti untuk merujuk kepada gerakan historis dari penduduk etnis Israel yang tersebar, perkembangan budaya penduduk itu, atau penduduk itu sendiri. ${ }^{3}$ Seiring waktu, istilah daspara juga digunakan dalam proses migrasi yang bukan saja pada pengusiran dari negara asal dengan kekuatan. O rang-orang Yahudi sendiri kadang-kadang lebih suka tinggal di diaspora Yahudi atau untuk bermigrasi dari satu diaspara ke daspora lainnya daripada kembali ke tanah air mereka. ${ }^{4}$

Bidang akademik dari studi diaspara mulai muncul pada akhir abad ke-20, sehubungan dengan meluasnya arti "diaspora." Jacob Riis menyimpulkan bahwa dasporaterbentuk pada pertengahan abad ke-20, namun pada kenyataannya makna diaspara yang diperluas baru diselidiki pada akhir abad ke-20. Pada abad ke-20 khususnya telah terjadi krisis pengungsi etnis besar-besaran, karena peperangan dan bangkitnya nasionalisme, fasisme, komunisme dan rasisme, serta karena berbagai bencana alam dan kehancuran ekonomi. Pada paruh pertama dari abad ke-20 ratusan juta orang terpaksa mengungsi di seluruh Eropa, Asia, dan Afrika Utara. Banyak dari para pengungsi ini yang tidak meninggal karena kelaparan atau perang pergi ke benua Amerika. ${ }^{5}$

Sementara itu, menurut Vertovec, diaspara menyangkut tiga hal, yaitu: proses penyebaran, masyarakat yang tinggal bagian asing, tempat atau ruang geografis di mana mereka tinggal di diaspora. Secara sosiologis dan antropologis masyarakat diasporik mengalami pola perubahan akibat interaksi dan adaptasi dengan masyarakat lokal. Pola perubahan seputar migrasi dan status minoritas biasanya meliputi: organisasi dan mobilisasi, politik pengakuan, posisi dan aturan tentang wanita, regenerasi, etnis dan pluralisme agama, identitas dan kemasyarakatan, praktik ritual, respasialisasi, jaringan: horisontal-vertikal, kesadaran identitas keagamaan global, lokalitas vs universalitas, reorientasi pengabdian, dan lintasan (trajetaries). ${ }^{6}$ Secara lebih luas, Steven Vertovec menjelaskan diaspora sebagai bentuk sosial,

${ }^{2}$ http:/ / id.wikipedia.org/ wiki/ Diaspora, diakses 13 O ktober 2010.

IIbid.

"Peter K. Waldmann, "Radicalisation in the Diaspora: Why Muslims in the West Attack Their Host Countries," dalam http:/ / www.realinstitutoelcano.org/ wps/ portal/ rielcano eng/ Content?WCM_GLOBAL_CONTEXT=/ elcano/ elcano_in/ zonas_in/dt9-2010. WP 9/ 2010 - 15/ 3/ 2010.

5Ibid.

"Steven Vertovec, "Religionc and Diaspara," dalam Peter Antes, Armin W. G eertz, Randi R.Warne, NewApproachs toStudy of Rdigion, vdume2: Textual, Comparative, Soidogical and CogitiveApproach(Berlin: de G ruiter G mbH \& Co, 2004). 
jenis kesadaran, dan model produksi budaya. ${ }^{7}$

a. Diaspora sebagai bentuk sosial

Pengalaman diaspara Yahudi- pengasingan traumatis mereka dari tanah air sejarah dan penyebarannya ke seluruh dunia-memberi konotasi agak negatif karena terkait dengan perpindahan paksa, viktimisasi, keterasingan dan kehilangan. Martin Baumann, sebagaimana dikutip Vertovec, menunjukkan tiga titik referensial berbeda sehubungan dengan pengalaman sejarah daspora Yahudi tersebut, yaitu: a) proses penyebaran, b) kehidupan sebagai orang asing, dan c) tempat atau geografis di mana sebuah kelompok hidup tersebar. Ciri-ciri umum diaspora meliputi: Hubungan sosial yang direkatkan oleh ikatan sejarah dan geografi, sehingga secara umum daspara dilihat sebagai: a) akibat dari migrasi sukarela atau terpaksa dari satu lokasi rumah, setidaknya dua negara, b) kesadaran mempertahankan identitas kolektif yang sering berkelanjutan dengan mengacu pada 'mitos etnis' suatu asal, pengalaman sejarah, dan beberapa jenis geografis, c) melembagakan jaringan pertukaran dan komunikasi yang melampaui negara-negara teritorial dan menciptakan organisasi-organisasi komunal baru di tempat-tempat pemukiman, d) mempertahankan berbagai hubungan eksplisit dan implisit dengan kampung halaman mereka, e) membangun solidaritas dengan anggota co-etnis di negara-negara lain, dan f) ketidakmampuan atau keengganan untuk sepenuhnya diterima oleh tuan rumah masyarakat sehingga memupuk perasaan keterasingan, penolakan, keunggulan, atau jenis perbedaan lainnya. ${ }^{8}$

Ketegangan orientasi politik masyarakat diaspark sering dihadapkan pada kesetiaan antara daerah asal dan negara tuan rumah. Para imigran bisa menjadi aktor yang signifikan, atau secara kelompok menjadi kelompok penekan politik dalam negeri, negara tuan rumah, dan arena politik internasional, serta biasanya karena kepentingan politik negara asal mereka. Relatif mudah transportasi dan komunikasi diasporasebagai bentuk sosial ditandai dengan hubungan triadcantara a) secara global kelompok-kelompok etnis tersebar secara kolektif, b) teritorial negara dan konteks di mana kelompok-kelompok tersebut berada, dan c) tanah air dan konteks mana mereka atau leluhur mereka datang.

b. Diaspora sebagai jenis kesadaran

Kesadaran diaspara adalah suatu bentuk kesadaran yang dihasilkan masyarakat transnasional kontemporer. Pendekatan ini menempatkan penekanan lebih besar pada menggambarkan berbagai pengalaman, keadaan pikiran dan rasa identitas. Diaspara, pada taraf tertentu, akan diadakan bersama-sama atau diciptakan kembali melalui pikiran, melalui artefak budaya dan melalui imajinasi bersama. D engan cara ini, diaspara berfungsi untuk menjembatani kesenjangan antara lokal dan global. Selain kesadaran multi-lokalitas dan link imajinasi, beberapa penulis telah menggambarkan kesadaran diaspora dengan cara fungsi lain dari pikiran. D alam bentuk apapun, diaspora selalu meninggalkan jejak memori kolektif tentang tempat dan waktu lain dan membuat peta baru keinginan dan

7Steven Vertovec, ThreeMeanings of "Diaspara": Exemplified ammgSauthAsian Reigions(University of O xford, daspara 7(2) in press, 1999), 2-4.

${ }^{8}$ Ibid., 4. 
perpindahan. Ingatan kolektif ini sering dibangun pada permainan kasar memori dan keinginan dari waktu ke waktu yang memiliki banyak lintasan (trajetories) dan rekahan yang kadang-kadang sesuai dengan politik generasi. ${ }^{9}$ Kesadaran diaspara kemudian dianggap sebagai sumber perlawanan melalui keterlibatan dengan, dan visibilitas dalam ruang publik.

c. Diaspora sebagai model produksi budaya

D alam pengertian diaspara sebagai model produksi budaya, meskipun tidak secara eksklusif, para antropolog melihat globalisasi sebagai aliran seluruh dunia budaya, objek gambar dan makna yang mengakibatkan beraneka ragam proses ceelisation badk dan transferences saling pengaruh, kontestasi baru, negosiasi dan transformasi konstan. D alam diaspara cara ini digambarkan sebagai melibatkan produksi dan reproduksi sosial dan fenomena budaya transnasional. Aliran konstan berbagai barang dan kegiatan telah tertanam di dalamnya hubungan antara manusia. Hubungan sosial ini mengambil makna dalam kehidupan sehari-hari, seperti hubungan antara masyarakat yang berbeda dipelihara, diperbaharui, dan disusun kembali dalam konteks keluarga, lembaga, investasi ekonomi, bisnis, dan keuangan dan organisasi politik dan struktur termasuk negara-bangsa. ${ }^{10}$

\section{Muslim Diaspora: Identitas, Gender dan Terorisme}

Umat Islam yang hijrah ke Barat meninggalkan tanah airnya demi kehidupan yang lebih baik di Eropa, Amerika, Australia dan belahan dunia lainnya. Ketika di Barat, mereka berusaha membangun kembali identitasnya, Islam mereka. Pada langkah pertama, mereka mengingatkan diri mereka serta keluarga mereka bahwa mereka telah memiliki sebuah identitas dan karenanya Islam menjadi pilar penting identitas mereka. Mereka bahu-membahu membangun masjid dan sekolah untuk melindungi sisa-sisa identitas masa lalu mereka dari kepunahan. Setelah mereka membangun identitasnya dan merasa kuat, mereka mulai memperkenalkan diri mereka kepada orang lain. ${ }^{11}$

Pola dasporasebenarnya merupakan konsep yang juga berakar dari khazanah peradaban Islam. Konsep ini berawal ketika Nabi Muhammad saw. hijrah dari Makkah ke Madinah. ${ }^{12}$ Di Madinah Nabi Muhammad membangun komunitas migran. ${ }^{13}$ Komunitas migran inilah

9Ibid., 8-9.

${ }^{10}$ Ibid., 19-21.

"TahaJabir al-Alwani, "Refleksi atas Perdebatan Muslim Moderat," dalam Suaidi Asyari, SiapakahMudimMoakat, 215.

${ }^{12}$ Refleksi hijrah yang membentuk migrasi Rasul saw. ke Madinah ketika itu adalah bentuk logis dan rasional dalam rangka membentuk peradaban madimat al-rasul, sebuah peradaban utama yang seluruh warganya dapat hidup dengan aman dan sejahtera. Ahmad Najib Burhani, misalnya, memahami "hijrah" sebagai sebuah sistem atau terbentuknya sistem sebagai keseluruhan relasi yang saling terkait, saling mempertahankan dan saling mengubah, tidak tergantung pada bentuk materialnya yang sangat berlainan, dapat ditemukan apa refleksi aturan yang serupa dari semua bentuk itu. Titik temu dari segala bentuk hijrah berkisar pada tiga fungsinya, yaitu: otoritas kekuasaan (power), ekonomi, dan pembentukan tatanan sosial baru, baik dalam agama, moral maupun peradaban. Ahmad Najib Burhani, IdamDinamis Menggugat PeranAgama, Menbongkar DdkninjangMenbatu(Jakarta: Kompas Media Nusantara, 2001), 172-173.

${ }^{13}$ Perlu dicatat bahwa muslim diasporabiasanya adalah muslim minoritas. O leh karena itu, penting untuk menelaah sedikit tentang konsep minoritas. Mengikuti definisi Kettani, secara sederhana, seseorang atau sekelompok kaum Muslim bisa dikategorikan sebagai minoritas. Pertama-tama, ia disebut minoritas karena soal jumlah yang kecil. 
yang kemudian menjadi cikal bakal peradaban muslim. Muslim migran terus berpikir bagaimana membangun komunitas yang mampu membaur dan tidak merasa terasing di tempat barunya dan merasa seperti di rumah sendiri. Namun demikian mereka tetap memiliki keterikatan dengan tempat asalnya, Makkah, dan terus melakukan pengkajian dan pemikiran bagi pembangunan dan pengembangan muslim di Makkah. Jadi, ide diaspora migran merupakan hal sentral dalam sejarah Islam. ${ }^{14}$

Hal ini bukan hanya karena Nabi merupakan titik sentral dalam sejarah Islam tetapi dalam masa-masa berikutnya konsep dasporajuga masih memegang peranan penting dalam pembangunan peradaban muslim. Misalnya kasus pembangunan kota Bagdad. Kota Bagdad pada hakekatnya juga dibangun oleh masyarakat muslim imigran. Ada dua khalifah yang berambisi membangaun Bagdad layaknya Yunani sebagai kota akademik, sehingga Bagdad menjadi sebuah pusat dari peradaban baru. Begitu juga komunitas muslim Spanyol, secara keseluruhan, terbentuk dari komunitas pengembara, muslim dari Mesir dan Maroko yang kemudian membentuk peradaban muslim. ${ }^{15}$

Di Spanyol inilah komunitas pemikir, penulis dan ilmuan muslim datang untuk membentuk budaya intelektual. Kemudian komunitas diaspara ini memberikan respon terhadap perkembangan dan tidak jarang menggeser pusat-pusat peradaban itu sendiri. Seperti Makkah sebagai pusat peradaban yang menjadi tanah kelahiran Islam digeser oleh Madinah, Madinah digeser oleh D amaskus, Damaskus oleh Bagdad dan seterusnya. ${ }^{16}$

Semua agama, termasuk ketiga agama samawi, telah berkembang pesat dan melahirkan peradaban besar justru setelah keluar dari tempat kelahirannya. Yahudi dan Nasrani lahir di wilayah Timur Tengah, namun berkembang pesat di Eropa dan Amerika. Islam yang lahir di Makkah dan Madinah pernah melahirkan peradaban besar setelah berkembang di Baghdad, Iran, Mesir, dan Spanyol. Kini Islam menyusul dan merambah dunia Barat mengikuti agama pendahulunya,Yahudi dan Nasrani. ${ }^{17}$

Sebagian besar Muslim berimigrasi ke Amerika setelah pengesahan the A sia Exclution Act di tahun 1960-an. Mereka memasuki Amerika yang telah mengesahkan UU hak-hak

Seseorang atau sekelompok orang dikatakan sebagai minoritasjika "kalah jauh dalam hal jumlah" dalam posisi diperbandingkan dengan kelompok pemeluk agama lain yang jumlahnyajauh lebih besar. Kettani mengerangkakan diskusi tentang minoritas mayoritas Muslim dalam konteks wadah negara-bangsa (nation state) bukan dalam wadah lain yang lebih alami dalam masyarakat, misalnya, etnisitas, kesukuan (qabilah), kebangsaan (Sha'b), dan kelompok (t女ifah). Dalam wadah sebuah negara-bangsa, sekelompok orang atau sejumlah warga negara yang memeluk agama Islam, karena jumlahnya kecil, dapat disebut sebagai minoritas Muslim jika kalah dalam hal jumlah dibandingkan dengan pemeluk agama lain di negara itu. D engan jumlah yang tergolong tidak seberapa itu, mereka kemudian mengalami berbagai masalah yang sesungguhnya tidak mereka harapkan (unintendedprddens), seperti termarginalisasi secara politik, kesulitan berintegrasi dalam negara-bangsa, secara sosio-kultural tersegregasi, terhimpit kesulitan ekonomi. Hasilnya, kaum minoritas Muslim membangun dan memelihara konsep, identitas, dan jati diri mereka sendiri. ${ }^{14}$ D engan suasana batin seperti itu, kaum minoritas Muslim seolah-olah berjalan ke arah yang berbeda daripada yang dicita-citakan negara-bangsa di mana mereka hidup. D engan demikian, minoritas Muslim sering menjadi persoalan yang pelik dan serba suram. Studi-studi tentang kaum minoritas mulai menjadi perhatian para ahli sejak 1950-an dan 1960-an. Pada dekade itu, para ahli politik di Barat mulai tertarik meneliti pengaruh formasi negara-bangsa di negara-negara yang baru merdeka terhadap pergeseran dan pengelompokan etnik di wilayah geografisnya. Lihat M. Ali Kettani, MinoritasMusimdi DuniaDenasaIni, terj. Zarkowi Soejoeti (Jakarta: Raja Grafindo Perkasa, 2005).

${ }^{15 Z}$ Ziauddin Sardar, Isamtampa Syan'at: Menggali Univesalitas Tradis (Jakarta: G rafindo K hasanah Ilmu, 2005), 32. ${ }^{16}$ Ibid.

${ }^{17}$ Ibid. 
sipil (Civil Rights Ad) tahun 1964 dan UU imigrasi tahun 1965. Saat itu Amerika sedang mengalami krisis identitas, sebuah negara yang merasa tidak nyaman dengan masa lalunya yang pernah rasis. Amerika yang telah mulai toleran terhadap identitas campuran dan secara pelan-pelan menganggap dirinya sebagai masyarakat pluralis. K arenanya, muslim menganggap Amerika akan memberinya kehidupan yang lebih baik. Beberapa imigran datang karena takut hukuman akibat afiliasi dengan gerakan-gerakan Islam..$^{18}$

Amerika Serikat (AS) yang bangga dengan masyarakatnya yang sangat plural lebih akomodatif terhadap kehadiran beragam agama dan budaya, termasuk Islam. Hanya saja setelah peristiwa 11 September 2001, umat Islam di sana merasa tertekan karena selalu dicurigai. Namun dibandingkan di Eropa, umat Islam di AS lebih baik kondisinya. Mereka lebih terpelajar, pusat-pusat studi Islam bermunculan, semua universitas besar di AS merasa belum lengkap jika belum memiliki Departemen Studi Islam dengan jajaran profesor ahli yang sebagian didatangkan dari dunia Islam. ${ }^{19}$ Namun mereka tetap merasa gamang dan bingung menemukan identitas dirinya. Meskipun lahir di Eropa, Amerika, Prancis dan lainnya, namun mereka tidak merasa sebagai orang Barat dan tidak pula merasa akrab dengan budaya asal usul orang tuanya. Ketika terjadi konflik rasial dan agama dengan pemerintah setempat, keturunan imigran muslim ini serba bingung. Mereka tidak memiliki rumah budaya dan tanah air yang memberikan kenyamanan. Mereka lahir dan berbicara dengan bahasa Barat, tetapi tidak memperoleh pengakuan sepenuhnya sebagai orang Barat. ${ }^{20}$

Hal tersebut terjadi karena, bagi para pemeluknya, Islam tidak sekadar sistem keimanan, melainkan juga ada seperangkat aturan dan kewajiban ritual serta etika sosial, kehadiran Islam di Barat bisa jadi sebagai canter sistem nilai sehingga benturan dengan tradisi setempat tidak bisa dielakkan. Secara kasat mata, kemunculan masjid dan tradisi salat Jumat, berpuasa, mengenakan jilbab, dan ketersediaan makanan halal menjadi fenomenal dan sering menimbulkan gesekan. Pendeknya, muslim diaspara saat ini telah menjadi objek tersendiri bagi peminat studi Islam di Barat khususnya. Problem muslim daspara yang demikian dapat digambarkan sebagai berikut.

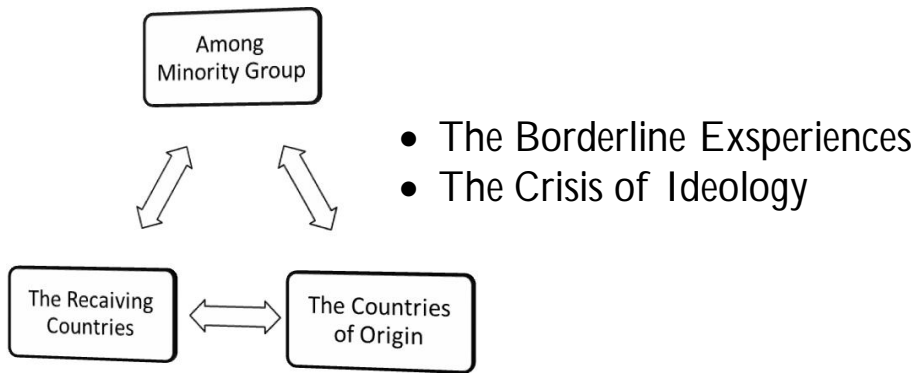

Muslim diaspara dihadapkan pada tiga persoalan pelik. Petama, kehidupan minoritas mereka dalam masyarakat mayoritas (ammg minority gaup), dengan adat, budaya, agama, sejarah, sosio politik dan ekonomi, sama sekali berbeda dengan kampung halamannya. Keelua, sikap dan penerimaan negara tuan rumah (the reciving cantries) ada yang adaptif karena

${ }^{18}$ Komaruddin Hidayat, dalam http:/ / www.uinjkt.ac.id/ index.php/ category-table/ 1275-muslim-diasporahtml, Jumat, 12 Februari 2010 10:14.

${ }^{19} Y$ vanne Yazbeck Haddad, “Pencarian Islam Moderat,” dalam Suaidi Asyari, SiapakahMusimModkat, 10-11. ${ }^{20}$ Ibid. 
traumatik terhadap pengalaman rasisme akut seperti Amerika, atau beban sejarah kolonialisme seperti kebanyakan negara Eropa di mana mayoritas muslim diaspora berasal dari negara-negara bekas jajahan mereka. Kehadiran muslim daspara sering mereka anggap sebagai ancaman eksistensi tatanan kehidupan yang telah mereka bangun berabad lamanya. Keiga, hubungan kaum diasporik dengan kampung halaman (thecantriesof oigin) dan pengaruh kepentingan negara asal atau kepedulian muslim dasparaterhadap kampung halaman menjadi persoalan tersendiri bagi kehidupan mereka di diaspara. Situasi baru ini (the bordeness exsperienes) menimbulkan dilema ideologis (thecias of idedogy) bagi muslim diaspara. Persoalan menjadi lebih rumit menimpa muslim diasparagenerasi kedua bahkan ketiga. G enerasi kedua dan ketiga ini merasa nyaman menjadi orang Barat (negara tuan rumah) karena lahir dan besar di Diaspara.

Oleh karena itu, penting untuk mengidentifikasi masalah-masalah yang dihadapi muslim diaspara dalam rangka memberikan sedikit sumbangan pemikiran atas problem tersebut. Problem muslim diaspara yang menjadi perhatian dunia terutama menyangkut beberapa isu penting, yaitu identitas, ${ }^{21}$ pluralitas, gender dan radikalisme/ terorisme.

\section{Identitas}

Identitas agama, etnik, dan politik hampir sulit dipisahkan. Secara antropologis ini juga berarti bahwa keberagamaan seseorang lebih banyak dipengaruhi oleh keturunan dan lingkungan, bukannya pilihan bebas. Tempat lahir, warna kulit, bahasa, dan agama merupakan realitas primordial yang diterima seseorang, bukan karena hasil usahanya sendiri. Meskipun demikian, seseorang setelah dewasa bisa saja berganti agama. Namun persentasenya sangat sedikit. Begitu juga pilihan politik, hubungan kekerabatan, dan paham keagamaan sangat signifikan pengaruhnya. ${ }^{22}$ Oleh karena itu, identitas menjadi hambatan besar bagi muslim dasparauntuk beradaptasi bahkan berintegrasi dengan negara baru mereka.

${ }^{21}$ Pola perubahan masyarakat diasporik pernah dipaparkan oleh D eddy Mulyana terhadap imigran Indonesia di Australia dalam penelitiannya, "Mengindonesia di Australia: Perubahan dan Kesinambungan Identitas Etnik." Setelah 30-40 tahun tinggal di Melbourne Australia, mereka mengalami transformasi identitas etnik. Secara umum model identitas etnik mereka dapat dikelompokkan menjadi: relijius, moderat, kosmopolitan dan nasionalis. Namun kecenderungan dominan adalah menjadi lebih relijius, yaitu: etnik moderat yang menjadi relijius, etnik nasionalis yang menjadi relijius, relijius yang menjadi semakin relijius.

\begin{tabular}{|l|l|l|l|}
\hline \multicolumn{1}{|c|}{$\begin{array}{c}\text { Model identitas } \\
\text { etnik }\end{array}$} & \multicolumn{1}{|c|}{ O rientasi waktu } & \multicolumn{1}{|c|}{ Kesetiaan dasar } & \multicolumn{1}{|c|}{ Significant others } \\
\hline Relijius & Terutama masa depan & Agama (Islam) & Muslim \\
\hline Moderat & $\begin{array}{l}\text { Masa kini, lalu dan } \\
\text { depan }\end{array}$ & $\begin{array}{l}\text { Negara asal, budaya dan } \\
\text { agama }\end{array}$ & O rang Indonesia \\
\hline K osmopolitan & Terutama masa depan & K emanusiaan universal & $\begin{array}{l}\text { O rang A ustralia dan } \\
\text { Indonesia }\end{array}$ \\
\hline Nasionalis & $\begin{array}{l}\text { Terutama masa lalu dan } \\
\text { kini }\end{array}$ & Negara Indonesia & O rang Indonesia \\
\hline
\end{tabular}

Lihat dalam lampiran buku D eddy Mulyana, Mehoodog Penditian Kualitatif ParadigmaBaruIlmuKommikas dan IlmuSosial Lainna, 233.

${ }^{22}$ Komaruddin Hidayat, "Agama, Etnisitas, dan Politik," Tulisan ini pernah dimuat di surat kabar Seputar Indonesia, Jumat 5 D esember 2008 dalam http:/ / www.uinjkt.ac.id/ index.php/ category-table/ 436-agamaetnisitas-danpolitik. 
Jeffrey Lang, seorang muallaf kulit putih Anglo-Saxon Amerika Serikat dalam sebagian besar kandungan buku EvenAngesAsk: A Jamey IdaminAmeika, menuturkan bahwa betapa konflik budaya dan konflik pemikiran, yang menghadang generasi muda Muslim maupun muallaf (pemeluk baru), merupakan persoalan dalam perkembangan Islam di Amerika Serikat. ${ }^{23}$

Ada beberapa kelompok masyarakat di Amerika yang sukar menerima Islam sebagai bagian budaya Amerika. Petama, generasi muda Muslim yang lahir dan besar di negara itu dan cenderung ingin menjadi "orang Amerika" ketimbang "orang Arab." Kedua, para muallaf kulit putih Amerika yang terbiasa dengan rasionalitas, yang akhirnya mutadkarena tidak bisa menerima kedangkalan berpikir komunitas Muslim yang terdominasi budaya A rab. Ketiga, masyarakat A merika yang mempunyai stereotip bahwa menjadi Muslim berarti menjadi orang Arab. Lang mengakui, sukar memang membantah stereotip, atau stigma tersebut. Sebab, "Ketika muncul dalam berita, para Muslim Amerika selalu berpakaian dalam jubah Timur Tengah." Selain itu, tambah Lang, simbol-simbol seperti pakaian Timur Tengah, ucapan-ucapan Arab, atau berjanggut, meneguhkan semua anggapan itu, sampai-sampai para muallaf dan sahabat Lang berkomentar kepadanya bahwa kaum Muslim mungkin mengira bahwa Tuhan "hanya mengerti bahasa A rab." ${ }^{24}$

Tidak heran, warga setempat yang masuk Islam mengalami krisis identitas dan konflik budaya. Di satu sisi mereka ditolak komunitas mereka sendiri, didiskrimnasi lantaran dianggap melakukan pengkhianatan budaya. Tetapi, di sisi lain, mereka pun tidak diterima komunitas Muslim sepenuhnya, karena sukar mengadaptasikan budaya Amerika yang sudah tertanam semenjak kecil, dengan budaya Arab yang asing..$^{25}$

Ketika mengkritik praktik dan pandangan yang bercorak Arab tradisional, sebagai contoh, mereka sering dituding kebarat-baratan dan dicap tidak islami. Apalagi, jika seorang Muslim mempertanyakan hukum Islam klasik atau kebiasaan yang mapan, ia dibungkam dengan tuduhan "hendak mengubah agama." Seorang Muslim justru dianggap saleh jika semakin menampilkan kebiasaan lahiriah yang tidak penting semisal mengenakan serban, gamis, memanjangkan janggut, dan mengucapkan idiom-idiom Arab. D isebabkan oleh pemahaman yang remeh ini, sebagian muallaf kulit putih berupaya keras menjadi "orang Arab" agar dapat diterima komunitas Muslim. Hal-hal seperti ini semakin memperkuat stereotip warga Amerika bahwa Islam identik dengan Arab. ${ }^{26}$

Contoh di atas menunjukkan bahwa identitas menjadi salah satu problem (baca: hambatan) bagi integrasi muslim daspora dengan negara tuan rumah. Setiap analisis dari "identitas" atau "komunitas" dapat dengan mudah akan berbicara mode esensialis yang melibatkan beberapa fenomena sosial (orang, bangsa, budaya, masyarakat agama, dll.) dan memberikan mereka ciri-ciri tertentu atau sifat abadi. Apa yang harus ditekankan

\footnotetext{
${ }^{23}$ Lihat buku BahkanMalaikatPunBetanya: MenbangunSikapBeislamyangKritis Judul aslinya adalah EvenAngeds Ask: aJaumeytoIdaminAmeika; Penulis: Jeffrey Lang; Penerjemah: Abdullah Ali; Penyunting: M.S. Nasrulloh; Pengantar: Murad Hoffman (edisi Amerika Serikat), Jalaluddin Rakhmat (Indonesia). Tebal: xvi + 302 halaman. Penerbit: Serambi 2001.

${ }^{24}$ Ibid.

${ }^{25}$ Ibid.

${ }^{26}$ Ibid.
} 
adalah rasa di mana konstruksi identitas kelompok secara inheren dengan proses sosial politik yang melibatkan dialog, negosiasi dan perdebatan mengenai "siapa kita?," "apa artinya menjadi?," "kita adalah?” dan lain-lain. ${ }^{27}$ Kesadaran dasporajuga dapat membahas khusus untuk kelompok agama. Hal ini terjadi melalui kesadaran diaspora digabungkan dengan pluralisme agama. D alam kondisi seperti itu, orang sering dipaksa untuk menyadari bahwa praktik kebiasaan rutin, belajar hafalan "iman buta" dan konteks sebelumnya (di mana iman mereka mungkin telah homogen atau hegemonik) tidak lagi operasional. D alam bahasa Clifford G eertz tentang pertanyaan utama telah bergeser dari "apa yang harus saya percaya (iman) " ke "bagaimana aku percaya?" 28

Sebagai gejala sosial, daspora tidak saja terjadi secara fisik dan material, tetapi juga budaya. Kendati tetap melestarikan budaya asal, para migran perlu melakukan negosiasi dengan budaya di tempat baru untuk melahirkan budaya baru. Dalam perspektif daspara, sedikitnya ada tiga pihak yang terlibat dalam arus pertukaran budaya. Petama, pelakunya sendiri, keedua, tempat baru yang dituju, dan keiga, generasi penerusnya. Konsep ini mengandung implikasi bahwa acuan terhadap budaya asal di tempat baru masih tetap relevan, walaupun besar kemungkinan secara terus menerus diproses dan berubah sesuai dinamika yang terjadi di tempat baru. Namun demikian, diaspara akan menampakkan komunitas budaya baru yang berbeda dengan komunitas budaya lain. ${ }^{29}$

Kesadaran diaspora dalam agama (Islam) yang tidak mampu (tidak mau) beradaptasi dengan lingkungan global sering menimbulkan konflik yang justru merugikan kelompok agama tersebut. Sebagaimana kritik Syafi'i Maarif terhadap Muslim diaspara di beberapa negara Eropa. D alam pandangan Syafi'i Ma'arif mereka yang berdasporake negara-negara Eropa adalah mereka yang tidak mendapat tempat yang layak di negaranya. Persoalannya, diaspara mereka juga dïringi dengan upaya islamisasi yang akhirnya akan menimbulkan benturan. O rang-orang yang berdiasparake Eropa berupaya mengislamkan E ropa dengan dakwah, sehingga mengalami benturan dengan pluralisme, demokrasi, gender, dan lainlain. Syafi'i Ma'arif menyarankan, seharusnya mereka bukan "mengislamkan Eropa" tetapi "mengeropakan Islam" sehingga Islam harus beradaptasi dengan pluralisme dan lainlain. ${ }^{30}$

\section{Gender}

Persoalan wanita dalam Islam akhir-akhir ini muncul dengan tajam tidak hanya karena umat Islam semakin menyadari pentingnya memahami dan menghidupkan kembali wawasan Islam tentang wanita tetapi juga karena, antara lain, ada benturan budaya Islam dengan budaya Barat modern. D alam hal pertama, pemunculan masalah wanita adalah

\footnotetext{
${ }^{27}$ Peter Mandaville, "Reimagining Islam in Diaspora: the Politics of Mediated Community," dalam GezetteVol. 63 (2-3) (London: Sage Publication, 2001), 169-186.

${ }^{28}$ Ibid.

${ }^{29}$ Mudjia Rahardjo, "Diaspora dalam Pergeseran Budaya dan Bahasa”, dalam http/ / mudjiarahardjacond artike/ 213-diaspora-dalamtpergesean-budaya-dan-bahasahtm. Rabu, 01 June 2010 01:12

${ }^{30}$ Syafi'i Ma'arif, "Politik Identitas dan Masa D epan Plularisme di Indonesia." Makalah orasi ilmiah dalam acara "Nurcholis Madjid Memorial Lecture III" yang diselenggarakan di Universitas Paramadina, Jalan G atot Subroto, Jakarta Selatan, Rabu (21/ 10), http:/ / www.voa-Islam.com/ Islamia/ liberalism/ 2009/ 10/ 23/ 1479/ syafii-maarifkalau-beragama-secara-hitam-putih-mungkin-lebih-baik-jadi-atheis/
} 
absah, otentik dan sejati (timbul dari keinginan murni). Sedangkan yang kedua, merupakan reaksi, dan terasa emosional, apologetik, ideologis dan tidak jarang subjektif, sekalipun dari celah-celahnya kadang-kadang memancar perenungan dan pemikiran kreatif dan orisinal..$^{31}$ Kebutuhan akan pembicaraan dan diskusi-diskusi tentang wanita menjadi lebih menarik bagi wanita muslim daspora Pertentangan antara mempertahankan identitas dan adaptif terhadap budaya Barat menjadi persoalan yang memerlukan perenungan yang tinggi.

Kemampuan muslimah diasporikyang tinggal dalam masyarakat Barat untuk praktik keyakinan agama mereka dan memiliki otonomi dalam pilihan yang mereka buat dibatasi oleh intervensi pemerintah dan penerimaan masyarakat yang lebih luas tentang hak-hak mereka pada pilihan dan praktik keagamaannya. Burca atau hijab perempuan, misalnya, telah mengidentifikasi mereka sebagai korban tertindas dan pasif yang merupakan gema dari era kolonial sebagai gambaran kegagalan untuk mengakui keragaman praktik keagamaan dan budaya di dunia Islam. Pengalaman perempuan Muslim dalam masyarakat Barat kontemporer masih terperosok dalam jenis konstruksi yang gagal untuk mengakui keragaman kepercayaan dan pentingnya praktik keagamaan mereka, baik diri mereka sebagai individu maupun sebagai komunitas. ${ }^{32}$

D alam wacana feminis mereka diserang karena pakaian mereka sebagai simbol penindasan daripada hak-hak mereka untuk menjadi siapa mereka dan perjuangan mereka untuk kebebasan beragama dan hak-hak sipil. D alam setiap wacana politik atau sosial, pakaian mereka dan praktik keagamaan dibangun untuk memvalidasi nilai-nilai Barat dan budaya berdasar praktik patriarkal Barat dan campur tangan politik di seluruh dunia non-Barat. Agar suara perempuan Muslim didengar dan pilihan mereka dihormati harus mampu meninggalkan masa lalu kolonial dan membangun citra baru berorientasi "lainnya." Dalam masyarakat Barat yang membanggakan diri pada cita-cita kebebasan demokratis dari kedua agama dan hak-hak sipil perempuan Muslim berdiri sebagai yang dikecualikan dari hak-hak ini. Jika perspektif Islam modern perempuan dihargai dan dipahami sebagai salah satu pilihan dan keanekaragaman kemudian barangkali masyarakat bisa fokus pada korban penindasan di seluruh dunia apakah mereka perempuan, miskin atau hitam. ${ }^{33}$

Pada akhir April 2010, pemerintah Belgia mengeluarkan undang-undang melarang perempuan Muslim dari mengenakan burqa atau niqab di tempat umum. D emikian juga Perancis juga mengikuti larangan yang sama. Nicolas Sarkozy menyatakan alasan larangan tersebut adalah bahwa burca merupakan simbol dari penindasan perempuan yang tidak akan diterima di Perancis. Hal ini mengakibatkan kurang dari 2000 perempuan dari populasi Muslim Prancis 5 juta akan terpengaruh oleh undang-undang ini, apalagi pemerintah Barat melihat para wanita muslim sebagai bahaya bagi tradisi dan budaya Barat. Perempuan Muslim telah dipersepsikan sebagai korban tertindas dan pasif, paradoksnya adalah bahwa

\footnotetext{
${ }^{31}$ Nurcholish Madjid, IdamA gama Peadaban: MerbangunMaknadanRdevani DdkninIslamdalamSgarah(Jakarta: Paramadina, 2008), 233.

${ }^{32}$ Bernadette James, "Lifting the Veil: Liberation or D iscrimination." To what extent do Muslim Women in the West have Autonomy to Practice Their Religion? Using Theory and Practical Examples D iscuss These Perspectives from a Muslim Point of View. http:/ / religionandsociety09. blogspot.com/ 2010/ 06/ lifting-veil-liberation-or.html ${ }^{33}$ Ibid.
} 
para wanita baik di Barat dan Timur telah terlibat dalam perjuangan untuk kebebasan beragama, politik dan sosial. Di Afghanistan, perempuan dibuat (dipaksa) untuk mengenakan burqa oleh rezim Taliban, dan di Barat mereka dipaksa untuk tidak memakainya. Timur dan Barat sama-sama gagal untuk mengakui kompleksitas dan keragaman perempuan Muslim dan praktik keagamaan mereka. ${ }^{34}$

\section{Radikalisme dan Terorisme}

Secara historis, istilah radikalisme, terorisme, dan fundamentalisme agama telah muncul dalam khazanah pemikiran agama. Namun istilah tersebut mengemuka secara signifikan setelah peristiwa pengeboman gedung WTC di New York pada 11 September 2001. Tragedi tersebut cukup mengancam masa depan Islam dan muslim diasparadi Barat, yaitu Islampobia. Bahaya ini memengaruhi isu-isu kewarganegaraan, kebebasan sipil, lapangan kerja dan bidang kehidupan lainnya. ${ }^{35}$

Ketika orang mendengar atau berbicara tentang radikalisasi, apa yang ada dalam pikiran mereka biasanya adalah fanatisme religius dan ekstremisme. Tapi radikalisasi agama barubaru ini menarik minat publik. Pada dekade sebelumnya, perdebatan mengenai radikalisasi difokuskan pada etnosentrisme dan nasionalisme. Di Afrika Utara dan Timur Tengah, gelombang fundamentalisme agama saat ini didahului oleh gelombang nasionalisme militan yang sebagian besar muncul dari masyarakat diaspara Sebagai contoh, salah satu pendukung utama perang pembebasan di Aljazair adalah komunitas Berber di Perancis. D emikian pula, Al Fatah Palestina, organisasi ini didirikan dan dibiayai selama bertahun-tahun oleh emigran Palestina yang tinggal di negara-negara Teluk. Di Lebanon peningkatan ekonomi dan politik Shi ‘h melahirkan pendirian sayap militer Hizbullah, dimungkinkan dibiayai oleh modal dan investasi Shisah yang telah bermigrasi ke Afrika Barat dan seterusnya ${ }^{36}$

Perbedaan antara nasionalisasi dan radikalisasi agama mungkin dianggap sebagai salah satu kriteria yang lebih jelas. Tetapi selain dari kenyataan bahwa sebagian kategori ini tumpang tindih, ada sejumlah besar kasus (orang Palestina, misalnya) di mana wacana diaspora telah berubah orientasi ideologis dari waktu ke waktu. D engan demikian, tipologi yang diusulkan Peter berdasarkan tiga kriteria yang berbeda: 1) perbedaan antara militansi daspora dikontrol oleh kekuatan-kekuatan eksternal (yang merupakan kepentingan terbatas dalam konteks kita) dan otonom militansi, 2) dalam hal militansi otonom, pertanyaannya apakah target dari militansi ini terletak di luar negeri (kebanyakan di negara asal) atau di negara tuan rumah, dan 3) jika negara tuan rumah itu sendiri adalah obyek dari agresi, pertanyaan apakah agresi ini ditujukan terhadap perlakuan rendah dalam masyarakat tuan rumah (pemberontakan) atau sebagai (serangan frontal) keseluruhan. ${ }^{37}$

Sedangkan, menurut Anne Aly, perkembangan ideologi kekerasan dan terorisme sangat didukung oleh sarana komunikasi, yaitu internet. Internet cukup memengaruhi kehidupan

${ }^{34}$ bid.

35John L Esposito, "Muslim Moderat: Arus Utama Kelompok Modernis, Islamis, Konservatif dan Tradisional," dalam Suaidi Asyari, SiapakahMudimMookat, 87.

${ }^{36}$ Peter K. Waldmann, "Radicalisation in the Diaspara: Why Muslims in the West Attack Their Host Countries," dalam http:/ / www.realinstitutoelcano.org/ wps/ portal/ rielcano eng/ Content?WCM_GLOBAL_CONTEXT=/ elcano/ elcano in/ zonas in/ dt9-2010. WP 9/ 2010 - 15/ 3/ 2010.

${ }^{37}$ Ibid. 
dan pemahaman keagamaan muslim diaspora, termasuk isu radikalisme dan terorisme. Untuk remaja muslim di Australia, internet telah menjadi salah satu sumber utama dari informasi keagamaan. Beberapa forum sejumlah besar muslim Australia dalam diskusi topik beragam seperti apakah Islam melarang memberi dan menerima hadiah natal. A pakah boleh atau tidak senjata pemusnah massal dapat digunakan dalam jihad bersenjata. ${ }^{38}$

D aya tarik internet untuk teroris terletak dalam kapasitasnya tidak hanya untuk memasuki penonton yang ada tetapi untuk menciptakan pemirsa baru di dalam ruang sosial di mana pengguna dapat berinteraksi dan membagi waktu dan ruang. Kedekatan internet dan teroris memberi patform untuk mempromosikan propaganda kepada audiens massa simpatisan potensial dan rekrutmen anggota baru. D alam lingkungan teroris kontemporer di mana perang psikologis memainkan bagian yang tidak terpisahkan, kehadiran di internet hampir sama penting bagi para teroris sebagai kemampuan taktis. Internet telah menjadi one stop shop untuk teroris: ruang komunikatif di mana mereka dapat mengidentifikasi, menginformasikan, mempengaruhi dan mengindoktrinasi. ${ }^{39}$

Namun demikian, ciri konteks Muslim diasporakontemporer dan yang berkaitan dengan penggunaan internet dan media lainnya dapat diidentifikasi, yaitu; a) transnasionalisme dan munculnya diaspara Muslim, b) pengembangan identitas bersama di kalangan umat Islam di seluruh dunia didasarkan pada perasaan menjadi korban dan pada konsep persaudaraan "ummah" yang melampaui batas-batas kebangsaan, etnis atau ras, c) sebuah persepsi yang dipegang secara luas di kalangan muslim diaspara bahwa media Barat adalah aktor yang terlibat dalam konspirasi untuk melemahkan Islam dan selanjutnya meninggalkan dengan media Barat sebagai sumber berita dan informasi, d) adanya krisis pribadi dan komunal. Krisis ini dibingkai dalam pertempuran ideologis bagi kelangsungan hidup Islam dan dinyatakan dalam perang (jihad kekerasan) antara Islam dan Barat. ${ }^{40}$

Prasangka muslim daspara tersebut diperparah dengan beberapa alasan global yang menjadi faktor kekerasan dan terorisme internasional. Beberapa faktor tersebut sebagaimana di kemukakan Ali A. Mazrui, ${ }^{41}$ adalah: a) Amerikanisasi Laten Timur Tengah yang dilakukan oleh para pemangku kebijakan Amerika. Amerika menjadikan Timur Tengah sebagai gelanggang manipulasi imperialis dan intervensi militer berkala. Pendudukan Amerika terhadap Afghanistan, Irak dan lainnya dianggap sebagai penghinaan terhadap umat Islam, b) pemicu kedua adalah prihal negara Israel, pendudukan yang brutal terhadap negara Palestina dan dukungan materi dan diplomatik yang tidak kritis, payung hukum yang besar, dan keengganan PBB mengutuk aksi-aksi brutal Israel menyebabkan frustrasi internasional (khususnya warga muslim dunia) dan menimbulkan kemarahan meluas di seluruh dunia, dan c) sebab domestik, yaitu sistem monarki Arab yang otoriter serta rezim-rezim muslim lainnya yang tidak demokratis.

Beberapa isu besar muslim diaspora tersebut sebenarnya bisa diatasi dengan menanggalkan egoisme dan menempatkan identitas secara proporsional. Beberapa hal berikut

\footnotetext{
${ }^{38}$ Anne Aly, "Online Radicalisation and the Muslim Diaspora," dalam http:// www.aspi.org.au/ research/ spf article.aspx?aid=61. 13 Jul 2009.

39ibid.

${ }^{40}$ Ibid.

${ }^{41} A$ li M. Mazrui, "Islam Liberal versus Islam Moderat: Para Moderat yang Sukar D ipahami dan Mentalitas Yang Sakit," dalam Suaidi Asyari, SiapakahMudimModarat, 187-188.
} 
ini mungkin bisa menjadi sedikit sumbangan bagi mencairnya hubungan Barat dan muslim diaspora.

\section{Dari Adaptasi ke Integrasi}

Kegagalan muslim daspora memosisikan identitasnya mungkin disebabkan kegagalan dalam berinteraksi, bersosialisasi, berasimilasi, beradaptasi, lebih-lebih melakukan integrasi terhadap negara tuan rumah. Perubahan kultur, bahasa, dan ras memerlukan kelapangan dada untuk beradaptasi dengan lingkungan. Parsons berasumsi bahwa setiap masyarakat tersusun dari sekumpulan subsistem yang berbeda berdasarkan strukturnya maupun berdasarkan makna fungsionalnya bagi masyarakat yang lebih luas. Ketika masyarakat berubah, umumnya masyarakat tersebut akan tumbuh dengan kemampuan yang lebih baik untuk menanggulangi permasalahan hidupnya. ${ }^{42}$ Menurut Parson, sebagaimana dikutip D wi Narwoko, mengajukan teori tentang tindakan manusia dengan membedakannya menjadi empat sub sistem: organisme, pessonality, sistem sosial dan sistem kultural. Keempat unsur ini tersusun dalam urutan sibernetika (ghbemetic arda) yang menurut Parson sebagai unsur yang mengendalikan tindakan manusia. ${ }^{43}$

Semua tindakan manusia ditentukan oleh keempat subsistem: budaya, sosial, kepribadian, dan organisme. Sistem kultural merupakan sumber ide, pengetahuan, nilai, kepercayaan, dan simbol-simbol. Untuk sampai pada tindakan nyata, pescmality, sistem sosial berfungsi sebagai mediator terhadap sistem kultural. Artinya simbol-simbol budayawi diterjemahkan begitu rupa dalam sistem sosial yang kemudian disampaikan kepada individuindividu warga masyarakat (sistem sosial) melalui proses sosialisasi dan internalisasi. ${ }^{44}$

Parsons menyampaikan empat fungsi yang harus dimiliki dalam sebuah dinamika perubahan agar mampu bertahan, yaitu: ${ }^{45}$

1. Adaptasi, kemampuan menanggulangi situasi eksternal yang gawat dan dapat menyesuaikan diri dengan lingkungan.

2. Pencapaian, sebuah sistem harus mendefinisikan dan mencapai tujuan utamanya. Muslim diaspara perlu memperjelas tujuannya tinggal di Barat agar dapat dinegosiasikan dengan budaya dan masyarakat tuan rumah.

3. Integrasi, mengatur hubungan antar bagian yang menjadi komponennya. Juga harus dapat mengelola hubungan antara ketiga fungsi penting lainnya.

4. Pemeliharaan pola, sebuah sistem harus melengkapi, memelihara dan memperbaiki motivasi individual maupun pola-pola kultural yang menciptakan dan menopang motivasi.

Masing-masing fungsi ini terkait dengan sebuah sub sistem, kerena subsistem ekonomi bertujuan untuk melakukan adaptasi, sub sistem politik bertugas memberi definisi tujuan akhir, subsistem kultural (agama, sekolah) bertugas untuk mendefinisikan dan memelihara norma-norma dan nilai, dan terakhir sub sistem sosial yang bertugas sebagai integrasi sosial. ${ }^{46}$ Homogenitas agama (Islam), dan ketegangan identitas yang mereka alami dalam negara

${ }^{42}$ Robert H. Lauer, PespaktiftentangPerubahan Sosial, terj. Alimandan (Jakarta: Rineka Cipta), 106-107.

43J. D wi Narwoko dan Bagong Suyanto, Sosidog:: TeksPengantar danTerapan(Jakarta: Kencana, 2004), 237. ${ }^{44}$ Ibid., 238.

${ }^{45}$ Anthony Giddens, et al., Sosidog: Sgjarah dan Bebbagai Penikiramnya, Para Pendin, Bebbagai Aliran Besamya dan Sosidog-sosidog Banu terj. Ninik Rochani Sjams (Yogyakarta: Kreasi Wacana, 2005), 107.

${ }^{46}$ Ibid., 108. 
tuan rumah yang beragam dalam hal lokasi kota-desa, budaya, agama, kelas dan gender, dan tidak mungkin diselesaikan dengan garis pengalaman standar umum untuk semua anggota muslim di diaspora Adaptasi dan integrasi adalah pertukaran dua arah yang membutuhkan tindakan proaktif asimilatif oleh imigran serta kesiapan untuk menghilangkan hambatan sosial dan ekonomi oleh masyarakat tuan rumah.

Beradaptasi dengan tetap mempertahankan identitas muslim mungkin pilihan terbaik. Dalam era global, fenomena globalisasi juga tampak jelas di sini. Tradisi lokal dibawa ke arena global. Muslim daspara, imigran muslim di E ropa, gerakan transnasionalisme menempati salah satu bagian dari kompleksitas kehidupan agama di era global ini. A pakah pada tempatnya yang baru di Eropa ini, para migran Muslim perlu menyusun dan menciptakan sistem kehidupan keagamaan sebagai hasil adaptasi dengan lingkungan sekitar yang baru, ataukah mereka masih bersikukuh mempertahankan sistem aturan fikih lama yang biasa digunakan dan dipraktikkan di tempat-tempat yang dihuni oleh mayoritas Muslim, baik di Timur Tengah, Pakistan atau Indonesia? A taukah mereka harus berpikir dan bertindak seolaholah mereka masih menghuni daratan dan bergaul sehari-hari dengan orang-orang atau masyarakat mayoritas muslim di negara asalnya dan tidak mempedulikan sama sekali sistem dan aturan kenegaraan dan keagamaan di tempat baru yang mereka huni selama tiga generasi untuk memenuhi kebutuhan ekonomi? Pertanyaan yang sama pernah diajukan secara sengit oleh pengikut Katolik di Indonesia dalam perbincangan mereka dengan pusat Katolik di Roma. Fikih mayoritas dan fikih minoritas kemudian muncul ke permukaan dengan tibatiba ketika pengikut agama dihadapkan pilihan-pilihan sulit ketika harus tinggal di tempat yang seharusnya ia tidak bertempat dan berdomisili di situ. Muslim diaspora sedang mencari solusi yang aman dari tarikan kepentingan fikih akthariyah atau aghlabiyah dan kemungkinan mempunyai kewenangan secara otonom menyusun sendiri sistem fikih aqalliyahyang adjustable dengan lingkungan setempat. ${ }^{47}$

\section{Dari Islam Jihadis ke Ijtihad Progresif}

Islam jihadis mengidentifikasi Islam dengan pilar tunggal, yaitu jihad, kemudian melanjutkannya dengan menawarkan interpretasi ulang terhadapnya. Kunci terhadap perdebatan ini adalah rangkulan Islam jihadis terhadap tindak kekerasan sebagai hal yang sentral dari perubahan sosial dan politik. Bagaimana seseorang bisa memahami perkembangan Islam jihadis sebagai tendensi teoretis_(teologis)? D apatkah pemahaman partikularnya terhadap teks al-Q ur'an dicerahkan oleh konteks perubahan historisnya? Tentu saja ya. ${ }^{48}$

Islam jihadis kontemporer yang merangkul kekerasan politik harus dipahami sebagai

\footnotetext{
${ }^{47} \mathrm{Amin}$ Abdullah, "Mempertautkan Ulum al-D in, al-Fikr al-Islamiælan D irasatIslamiyah: Sumbangan Keilmuan Islam untuk Peradaban Global." Makalah disampaikan dalam Seminar "45 Tahun Fakultas Ushuluddin dan Temu Alumni Pertama IAIN Al-Raniri", Banda Aceh, tanggal 29 Nopember 2008. Sebagian yang lain disampaikan dalam Seminar Nasional tentang "Kontestasi Pendidikan Agama dan Budaya G lobal" , Balitbang, D epartemen Agama, Bekasi, tanggal 1 Desember 2008. Penyempurnaan tulisan dari kedua seminar tersebut kemudian disampaikan dalam 'Workshop Pembelajaran Inovatif Berbasis Intergrasi-xInterkoneksi," UIN Sunan Kalijaga Yogyakarta, tanggal 19 D esember 2008.

${ }^{48}$ Mahmood Mamdani, "Kultur Berbicara: Enam Perdebatan yang Membentuk Wacana Muslim yang Baik," dalam Suaidi Asyari, SiapakahMusimModkat, 234-235.
} 
sebuah proyek modernis, tetapi bukan sebagai sisa masa premodern yang tertinggal di zaman modern ini. Kekerasan telah berada pada hati modernitas politik: Setidaknya sejak Revolusi Perancis (1789), masyarakat modern telah memikirkan tentang kekerasan sebagai hal yang sentral untuk maju. Diktum Marx bahwa revolusi adalah dukun beranak dari sejarah adalah bagian dari perspektif modernis ini. Tidak ada abad yang sama mengasikkan dengan kemajuan abad kedua puluh, dan tidak ada juga yang lebih keras. Tetapi harus diingat bahwa mereka yang hidup selama masa abad itu sangat mungkin untuk berpikir dari yang paling keras 'revolusi' perang-perang dunia, sebagai kekerasan "yang baik" bukan "kekerasan yangjahat." 49

Perjuangan jihad Afghanistan merupakan rumah panas di mana pelaku utama (prdagnist) yang memunculkan perang melawan teror saat ini- neocons (neo-konservatif) dan jihadisecara ideologis dan politis. D alam reformulasi mereka tentang Islam sebagaimana yang berhenti pada satu rukun/ pilar jihad sebagian besarnya militer, dan dari jihad militer tidak lagi tentang pertahanan diri masyarakat tetapi pernyataan yang tegas dari seorang individu, Islam jihadis harus dipahami sebagai bentuk Islam yang bangun kembali sebagai lawan dari Kristen dan Yahudi bangun kembali di masa kontemporer ini..$^{50}$ Pola pikir emosional Islam jihadis yang cenderung menawarkan kekerasan dalam setiap sikap politik dan keagamaan selain dipengaruhi oleh faktor eksternal juga dipengaruhi oleh cara pandang dan pemikiran terhadap Islam. Oleh karena itu, perlu mengubah cara pandang tekstual ke kontekstual dengan jalan ijtihad progresif.

Abdullah Saeed mengidentifikasi tiga model ijtihad yang menurutnya sangat berpengaruh pada masanya masing-masing sepanjang sejarah hukum Islam. Petama, adalah text-based ijihad, yakni metode ijtihad yang lazim dilakukan oleh fuqaha>klasik dan masih memiliki banyak pengaruh di kalangan pemikir tradisionalis. Pada model ini text berkuasa penuh, baik itu nas\$'Qurani>hłdith ataupun pendapat ulama sebelumnya baik yang berupa ijmasataupun qiyas Kedua, adalah edectic ijtihad, yakni upaya memilih nass/atau pendapat ulama sebelumnya yang paling mendukung pendapat dan posisi yang diyakininya. Yang ada adalah upaya justifikasi bukan pencarian kebenaran. Ketiga, adalah context-basedijtihad, sebuah fenomena baru yang menco ba memahami masalah-masalah hukum dalam konteks kesejarahan dan konteks kekiniannya (modern). Pada biasanya, pendapat akhirnya akan mengacu pada kemaslahatan umum sebagai macasid al-shar''ah ${ }^{51}$

Ijtihad model ketiga inilah yang dilakukan oleh para progressive ijtihadists. Kalau metodologi klasik biasanya memecahkan permasalahan hukum dengan mendasarkannya pada teks al-Qur'an, kemudian memahami apa yang dikatakan teks tentang permasalahan tersebut, dan paling jauhnya kemudian menghubungkan teks itu dengan konteks sosiohistorisnya ${ }^{52}$ maka progessiveijihadists mencoba lebih jauh lagi menghubungkannya dengan

${ }^{49}$ Ibid.

50Ibid.

${ }^{51} \mathrm{Abdullah}$ Saeed, IsamicThought and Introduction (London and New York: Routledge, 2006), 55. Kategorisasi ijtihadseperti di atas memiliki kelemahan mendasar pada poin yang kedua, yaitu eleticijithad Ketika dinyatakan bahwa ijtihad model ini adalah upaya untuk justifikasi "kepentingan" maka sesungguhnya sudah ke luar dari definisi ijthadyang disepakati oleh jumhur usjlityin, yaitu upaya sungguh-sungguh untuk menemukan status hukum shara' dari dalil-dalil yang ada. Menegasikan teks dan sejarah yang berposisi berbeda dengan kepentingannya adalah bukti tiadanya kesungguhan dalam pencarian kebenaran, melainkan emosi mencari pembenaran.

${ }^{52} \mathrm{~A}$ bdul Hamid A. Sulayman mengkritik metode berfikir fuqaha klasik pada dua hal yang sangat substansial. Petama, adalah ladk empinasm (tiadanya empirisisme) sebagai akibat tidak digunakannya milti-disaplinaryapproad, 
konteks kekinian seperti Esack, Irshad Manji, Ebrahim Moosa dan tentu Khaled Abou el Fadl.

Berkaitan dengan bagaimana metodologi progessive ijtihadists menafsir ulang teks-teks al-Qur'an, Abdullah Saeed memaparkan tujuh pendekatan utama yang tidak jauh berbeda dengan A bou el Fadl, yaitu: a) atensi pada konteks dan dinamika sosio-historis, b) menyadari bahwa ada beberapa topik yang tidak dicakup oleh al-Q ur'an karena waktunya belum tiba pada waktu diturunkannya al-Q ur'an, c) menyadari bahwa setiap pembacaan atas teks kitab suci harus dipandu oleh prinsip kasih sayang, justice dan fairness, d) mengetahui bahwa alQ ur'an mengenal hirarki nilai-nilai dan prinsip, e) mengetahui bahwa dibolehkan berpindah dari satu contoh yang konkret pada generalisasi atau sebaliknya, f) kehati-hatian harus dilakukan ketika menggunakan teks lain dari tradisi klasik, khususnya yang berkaitan dengan otentisitasnya, g) fokus utama pada kebutuhan muslim kontemporer. ${ }^{53}$ Pendekatan terhadap teks seperti inilah yang menurut Saeed akan mampu memberikan jawaban atas permaslahan kontemporer. ${ }^{54}$ D engan ijtihad progresif inilah diharapkan mampu melahirkan "fikih dasporik" yang dapat menjadi solusi terhadap problem-problem keagamaan muslim diaspora Fikih daspark bisa juga digunakan sebagai langkah awal adaptasi dan integrasi budaya yang berperspektif tamu dan tuan rumah.

\section{Dari Lokal ke Global}

Menurut Amin Abdullah, istilah ad loally and think gdbally (bertindak dan berbuatlah di lingkungan masyarakat sendiri menurut aturan-aturan dan norma-norma tradisi lokal serta berpikir, berhubungan dan berkomunikasilah dengan kelompok lain menurut cita rasa dan standar aturan etika global) sudah mulai muncul ke permukaan sejak dekade delapan puluhan, namun hingga sekarang, seperempat abad kemudian belum juga ketemu formula yang jitu tentang hal tersebut. Pengalaman kemanusiaan merasakan hal-hal yang sebaliknya. Bukannya kedamaian, mitual trust, peaceful cexistence, al-ta'ayus al-silm tolerance, tasamuh antarsesama dan antarkelompok umat manusia, tetapi justru kekerasan, vidence, prgudice (buruk sangka), sưal-złann keagamaan, etnisitas, kelas, ras, kepentingan, baik di tingkat lokal, regional, nasional maupun internasional. Seolah-olah semua ingin membalik adagium at and think locallyonlytanpa harus dibarengi think gdbally. D alam bergaul, berhubungan dan berkomunikasi dengan kelompok lain tidak merasa perlu mempertimbangkan dan

sperti sosiologi, psikologi, ekonomi dan lainnya dalam proses penetapan hukum. Keelua, adalah ladk of oerall ssstemzationsebagaimana yang juga dinyatakan oleh Ismail R. al-Faruqi dan Fazlur Rahman. Lihat bukunya yang berjudul Towards an Isamic Theary of Intemational Reations NewDiretion for Methodbloy and Thaught (H erdon, Virginia: IIT, 1993), 87-94.

53ID SS, "Progressive Islam and the State in Contamporary Muslim Societies." Laporan seminar diadakan di Marina mandarin Singapure tanggal 7-8 Maret 2006, 5.

${ }^{54}$ Ijtihad peogresif yang pernah dikemukakan oleh Saeed dan sejalan dengan gagasan al-Fadl adalah ketika ia mengkritik interpretasi bunga kaum neo-revivalis juga para ekonom muslim. Menurutnya, pengharaman riba dalam al-Q ur'an lebih didasarkan pada pertimbangan-pertimbangan moral dan kemanusiaan dan bukan pertimbangan hukum. Pengharaman bunga dengan alasan hukum adalah pemerkosaan atas otoritas teks. Terlebih lagi perbankan shariłh telah gagal membuktikan diri sebagai sistem intermediasi keuangan yang bebas riba. Pemberlakuan transaksi mrabahthdengan mark upkeuntungan hanyalah rekayasa akad hukum yang pada hakekatnya sama dengan bunga. Lihat A bdullah Saeed, Menyoal Bank Shar'ah: Kritik atasInterpreasi Bunga Bank KaumNeo Reivalis, terj. Arif Maftuhin (Jakarta: Paramadina, 2004). 
mengindahkan tata aturan, hukum-hukum, kesepakatan-kesepakatan dan hubungan international. Masing-masing kelompok etnis, agama, kelas, kultur ingin mempertahankan, bahkan sekte, mazhab atau aliran pemikiran tertentu ingin mengokohkan dan mempertegas identitas lokal keagamaan, identitas kultural, identitas etnis, identitas politik karena merasa di bawah bayang-bayang ancaman dominasi dan hegemoni kultur, budaya atau peradaban asing tertentu. Tekanan psikologi sosial yang nyata maupun yang dibayangkan ini kemudian menimbulkan perlakuan tidak adil (injustice, diskriminatif (perilaku politik yang membedabedakan ras, suku, agama, asal usul) dan subordinatif (merendahkan dan tidak menganggap penting kehadiran orang atau kelompok lain). Apa yang salah di sini? What wetturong? seolaholah tidak ada masalah dalam mempertahankan identitas dan jati diri kelompok, tetapi letupan-letupan yang muncul dalam peristiwa lokal, regional, nasional maupun internasional membuktikan ada masalah dalam tatanan pergaulan dunia. ${ }^{55}$

Berpikir global berarti berpikir universal, tentang keadilan, kemanusiaan, HAM, lingkungan, kemiskinan dan lain sebagainya. Pengalaman Farid Esack berinteraksi dengan mon muslim dalam menangani masalah-masalah universal kemanusiaan justru meningkatkan rasa iman dan pemahaman terhadap Islam dengan cara yang benar. Kemampuannya berinteraksi, beradaptasi bahkan berintegrasi dengan empati yang tinggi memberikan jalan baginya untuk memperkenalkan Islam yang rahlmah li al'‘lamin tidak hanya dalam retorika belaka, sebagaimana pengakuannya: "Sikap saya mempertahankan iman lebih banyak dikarenakan tersentuh oleh rasa kemanusiaan dari orang-orang yang secara agama berbeda dengan saya (therdigias dhe). Hal ini berarti bahwa, bagi mereka yang bukan Muslim, saya merasa tertantang untuk menemukan sebuah ruang di dalam lingkup aqidah saya sendiri, namun pada saat yang sama saya secara penuh tetap komitmen untuk menyaksikan kemurahan dan kasih sayang seorang Pencipta Yang Maha Pengasih, sebagaimana hal itu terlihat dari perbuatan yang baik dan bijak dari orang-orang biasa, baik laki-laki maupun perempuan." 56

Farid Esack berhasil melakukan adaptasi bahkan integrasi dengan tetap mempertahankan identitas muslimnya dengan satu keyakinan bahwa keimanan seseorang tidak boleh membelenggu kehidupan seseorang, tetapi harus mampu membebaskan ummatnya dari belenggu ketidakberdayaan. D engan cara ini, Islam bukan saja untuk umat Islam tetapi juga menjadi rahmat bagi dunia.

\section{Penutup}

Berdasarkan uraian di atas, nampak bahwa muslim diaspora belum menemukan pola diaspara ideal yang mampu menjadi solusi bagi problem kehidupan mereka, terutama menyangkut identitas, gender dan isu terorisme. Oleh karena itu, dibutuhkan fikih daspora sebagai sarana atau jembatan bagi integrasi budaya tanpa harus melepaskan identitas

\footnotetext{
${ }^{55} \mathrm{Amin}$ Abdullah, "Mempertautkan 'Ulum al-D in, al-Fikr al-Islamiælan D irasat Islamiłah: Sumbangan Keilmuan Islam untuk Peradaban Global." Makalah disampaikan dalam Seminar "45 Tahun Fakultas Ushuluddin dan Temu Alumni Pertama IAIN Al-Raniri," Banda Aceh, tanggal 29 Nopember 2008.

${ }^{56}$ Meskipun Esack tidak mengalami diasporasecara geografis, tetapi pengalaman adaptasi dengan kelompok yang berbeda bisa dijadikan contoh bagi muslim diaspora untuk bisa hidup damai di tengah perbedaan. Lihat Farid Esack, On Bënga Musim Merjadi Musimdi Dunia Modam, terj. D adi D armadi dan Jajang Jahroni ( Jakarta: Erlangga, 2002), 6.
} 
keisalamnnya. Hal tersebut bisa dilakukan dengan ijtihad progresif bagi problem-problem kehidupan mereka, dengan kearifan lokal dan berperspektif global. Prinsip al-mihafazth 'ala`al-cadim al-salih/wa al-akhdh bi al-jadid al-askah/dengan pemahaman yang luas menjadi penting dipegangi oleh muslim daspora supaya mampu menempatkan identitas muslim di satu sisi dan beradaptasi bahkan berintegrasi pada sisi yang lain. Hal ini membutuhkan tindakan proaktif asimilatif oleh muslim diaspora serta kesiapan untuk menghilangkan hambatan sosial dan ekonomi oleh masyarakat tuan rumah. Muslim daspara menemukan pengalaman identitas multi-dimensi yang terdiri dari jenis kelamin, agama, sekularisme, etnis, nasionalisme, dan kelas antara penanda lain. Islam tidak singulanizeatau menyederhanakan identitas atau pengalaman setiap muslim, itu hanya salah satu faktoryang membentuk identitas mereka. Membuat Islam yang słaihli kull zaman wa makanmerupakan tantangan bagi muslim diaspora.

\section{Daftar Rujukan:}

Abdullah, M. Amin. "Mempertautkan 'Ulum al-D in, al-Fikr al-Islamiðdan D irasat Islamiyah: Sumbangan Keilmuan Islam untuk Peradaban Global." Makalah disampaikan dalam Seminar "45 Tahun Fakultas Ushuluddin dan Temu Alumni Pertama IAIN Al-Raniri", Banda Aceh, tanggal 29 Nopember 2008.

Aly, Anne. "Online Radicalisation and the Muslim Diaspora." http:/ / www.aspi.org.au/ research/spf_article.aspx?aid=61. 13 Jul 2009.

Alwani (al), Taha Jabir. "Refleksi atas Perdebatan Muslim Moderat," dalam Suaidi Asyari, Siapakah Musim Modkat.

Burhani, A hmad N ajib. Isam Dinamis Menggugat Peran Agama, Merbangkar Ddkrin yang Menbatu Jakarta: Kompas Media Nusantara, 2001.

Esack, Farid. On Being a Musim Merjad Musimd Dunia Modkm, terj. D adi D armadi dan Jajang Jahroni. Jakarta: Erlangga, 2002.

Esposito, John L. "Muslim Moderat: Arus Utama Kelompok Modernis, Islamis, Konservatif dan Tradisional," dalam Suaidi Asyari, Siapakah Musim Modkat.

Faruqi (al), Ismail R. dan Rahman, Fazlur. Tovards an Isamic Theory of Intemational Rdations: NewDiretion for Methoddogy and Thangt. Herdon, Virginia: IIT, 1993.

Giddens, Anthony, et al. Sosidog: Sejarah dan Berbagai Penikirannya, Para Pendin, Berbacgi Aliran Besamya dan Sosidog-sosidog Banu terj. Ninik Rochani Sjams. Yogyakarta: Kreasi Wacana, 2005.

Haddad, Yvanne Yazbeck. "Pencarian Islam Moderat," dalam Suaidi Asyari, SiapakahMusim Moderat.

Hidayat, Ko maruddin. http:/ / www.uinjkt.ac.id/ index.php/ category-table/ 1275-muslimdiasporahtml, Jumat, 12 Februari 2010 10:14.

http:/ / id.wikipedia.org/ wiki/ Diaspara, diakses 13 O ktober 2010.

ID SS. "Progressive Islam and the State in Contamporary Muslim Societies." Laporan seminar diadakan di Marina mandarin Singapure tanggal 7-8 Maret 2006, 5.

James, Bernadette. "Lifting the Veil: Liberation or Discrimination." http:/ / religionandso ciety09. blogspot.com/ 2010/ 06/ lifting-veil-liberation-or.html 
Kettani, M. Ali. Minaritas Musim di Dunia Denasa Ini, terj. Zarkowi Soejoeti. Jakarta: RajaG rafindo Perkasa, 2005.

Lauer, Robert H. Pespaktif tentang Penubahan Sosial, terj. Alimandan. Jakarta: Rineka Cipta, t.th.

Ma'arif, Syafi'i. "Politik Identitas dan Masa D epan Plularisme di Indonesia." Makalah orasi ilmiah dalam acara "Nurcholis Madjid Memorial Lecture III" yang diselenggarakan di Universitas Paramadina, Jalan Gatot Subroto, Jakarta Selatan, Rabu (21/ 10), http:/ / www.voa-Islam.com/ Islamia/ liberalism/ 2009/ 10/ 23/ 1479/ syafii-maarif-kalauberagama-secara-hitam-putih-mungkin-lebih-baik-jadi-atheis/

Madjid, Nurcholish. Islam Agama Peradaban Membangun Makna dan Redeansi Ddknin Isam dalam Sgarah Jakarta: Paramadina, 2008.

Mamdani, Mahmood. "Kultur Berbicara: Enam Perdebatan yang Membentuk Wacana Muslim yang Baik," dalam Suaidi A syari, Siapakah MusimMookat.

Mandaville, Peter. "Reimagining Islam in D iaspora: the Politics of Mediated Community," dalam Gezette Vol. 63 (2-3). London: Sage Publication, 2001.

Mazrui, Ali M. "Islam Liberal versus Islam Moderat: Para Moderat yang Sukar Dipahami dan Mentalitas Yang Sakit," dalam Suaidi Asyari, Siapakah Musim Moderat.

Narwoko, J. D wi dan Suyanto, Bagong. Sosidog: TeksPengantar dan Terapan Jakarta: Kencana, 2004.

Pipes, D aniel. "Mengidentifikasi Muslim Moderat," dalam Suaidi Asyari, Siapakah Musim Modkat. Jakarta: G aung Persada Press, 2008.

Rahardjo, Mudjia. "Diaspora dalam Pergeseran Budaya dan Bahasa". http:// modjiarahardjocom/ artikd/ 213-diasparadalampergeseran-budaya-dan-bahasahtml. Rabu, 01 June 2010 01:12

Saeed, Abdullah. IslamicThaught and Introduction London and New York: Routledge, 2006.

- - - - . Menyoal Bank Shar'ah: Kritik atas Interpraas Bunga Bank KaumNeoRerivalis, terj. Arif Maftuhin. Jakarta: Paramadina, 2004.

Sardar, Ziauddin. Islam tampa Syan'at: Menggali Universalitas Tradisi. Jakarta: G rafindo K hasanah Ilmu, 2005.

Vertovec, Steven. "Religionc and Diaspara," dalam Peter Antes, Armin W. Geertz, Randi R.Warne, NewA proadhes to Study of Reigion, vdume 2: Textual, Comparative, Socidogical and CogitiveAppradh Berlin: de G ruiter G mbH \& Co, 2004.

- - - - . Three Meanings of "Diaspara": Exemplified among Sath Asian Rdigins Oxford: University of Oxford, 1999.

Waldmann, Peter K. "Radicalisation in the Diaspora: Why Muslims in the West Attack Their Host Countries." http:/ / www.realinstitutoelcano.org/ wps/ portal/ rielcano_ eng/ Content?WCM_GLOBAL_CONTEXT=/ elcano/ elcano_in/zonas_in/ dt9-2010. WP 9/2010 - 15/3/2010. 